\title{
Modelling and Implementation of Proactive Risk Management in e-Learning Projects: A Step Towards Enhancing Quality of e-Learning
}

\author{
Haneen Hijazi ${ }^{1}$ \\ Faculty of Information Technology \\ Hashemite University \\ Zarqa, Jordan
}

\author{
Bashar Hammad ${ }^{2}$ \\ Department of Mechanical and \\ Maintenance Engineering \\ German Jordanian University \\ Amman, Jordan
}

\author{
Ahmad Al-Khasawneh ${ }^{3}$ \\ Faculty of Information Technology \\ Hashemite University \\ Zarqa, Jordan
}

\begin{abstract}
The introduction of e-Learning to higher education institutions has been evolving drastically. However, the quality of e-Learning becomes a central issue in order to provide all stakeholders with the necessary confidence to compete with traditional learning methods. Risk management plays a vital role in the successful implementation of e-Learning projects and in attaining high-quality e-Learning courses. Little research has been conducted about implementing risk management in eLearning projects. This work proposes a quality assurance framework for e-Learning projects. This framework comprises a proactive risk management model that integrates risk management into the e-Learning process. This integration helps in obtaining high-quality e-Learning courses by preventing negative e-Learning risks from being materialized. The model is verified to evaluate its effectiveness through a Renewable Energy Course that was converted from a traditional face-to-face into eLearning course. Quantitative and qualitative measures are performed to analyze the data collected through the implementation of the project. The results show that the proposed model is managed to mitigate the majority of probable risk factors leading to high-quality e-Courses development and delivery.
\end{abstract}

Keywords-e-Learning; technology-enhanced learning; quality; proactive risk management; risk factors; higher educatio

\section{INTRODUCTION}

The existence of many Higher Education Institutions (HEIs) today could be ascribed to their abilities to keep pace with the continuous technological changes. Some institutions feel overwhelmed by these changes. Some otherwise consider them as inevitable dimension to strengthen their competitive advantages. The major revolution in technology has been the evolution of Information and Communication Technology (ICT) in the recent decades. Indeed, the evolution is not in the technology itself but rather in its applications in knowledge, information sharing, and education. One of the most effective ICT applications is what is now referred to as e-Learning.

In its simplest definitions, e-Learning means doing learning activities electronically through the Internet [1]. It is considered a key part of distance education [2]. Some definitions restrict e-Learning to the delivery of the e-Content over the Internet. Broader definitions widen the concept to cover the interaction among participants too, delivered by different communication technologies, mainly the Internet [3]. This delivery could be fully online, or a hybrid approach that integrates electronic learning and traditional classrooms in what is so-called blended learning [4].

e-Learning has got through Higher Education (HE) drastically over the last few years. HEIs have recently recognized the importance of e-Learning in reducing operating cost and increasing students' satisfaction. Indeed, these issues are necessary but not sufficient for a university to achieve the desired competitive advantage. As quality has been playing an increasingly important role in the educational system [5], universities need to guarantee a high quality e-Learning to compete strongly.

Despite that e-Learning activities highly penetrate $\mathrm{HE}$, quality of e-Learning has been an issue of debate. It was difficult to define what quality means to e-Learning courses. Several conceptual models and approaches rose recently, but the actual practice of quality of e-Learning in HEIs is still poor. Moreover, most of these approaches focus solely on the courses quality and the learning outcomes. Indeed, an overall detailed process-oriented quality assurance framework must exist and be followed during the e-Learning process to ensure the quality of the entire course, not only the output [6].

e-Learning projects deal with design, implementation, and utilization of social and information technological systems [7]. These systems involve several software applications (e.g. Learning Management System (LMS) and e-Content). However, there is no theoretical basis for project management that is specific to e-Learning [8]. Hence, most e-Learning projects management approaches follow software project management methodologies and inherit their characteristics because developing educational software shares several aspects with software development [9]. Mainly, it is the learning component what differentiates e-Learning projects from other types of projects [10]. Building upon this, the successful implementation of an e-Learning project requires balancing between project schedule, budget, and quality. Since the eLearning process is mainly characterized by its quality, competitive universities should put the quality of the eLearning projects at the forefront despite other challenges. 
Both success factors and possible failures together should be taken into account to increase the probability of project success. These possible failures are called risks. An e-Learning project inherits all types of risk factors encountered in Information System projects beside many other risks that are specific to e-Learning [11]. These factors might negatively affect the quality of the e-Learning course being developed and/or the learning outcomes, project schedule and/or resources. Many risk factors are associated with e-Learning projects [12]. These factors can be personal or dispositional, learning style, instructional, situational, organizational, content suitability, and technological [13]. In order to minimize their negative impact, these factors must be managed carefully [14]. Successful management of e-Learning risk factors would improve the quality of the e-Learning process and, consequently, the competitive advantage of the institution. Hence, Risk management should be the core competence in eLearning projects.

Risk Management is an important part in project management and very crucial for project's success. Indeed, this fact applies to all types of projects. Risk management involves predicting risks that might negatively affect the project schedule, budget or quality, and taking measures to avoid or mitigate the impacts arising from those risks [15]. Risk management in e-Learning projects could be defined as the set of principles, practices, procedures, methodologies, and tools aimed at identifying, analyzing and handling risk factors that could negatively affect the content development and delivery process and hinder the e-Learning project from achieving its desired outcomes. In e-Learning projects, risk management is a critical discipline that helps in reducing uncertainty, avoiding rework, improving content quality, making e-Learning process more reliable, decreasing learner's dissatisfaction and increasing the overall success chances. Several approaches to risk management exist. Reactive risk management does not apply mitigation strategies till the occurrence of the risks. Reactive risk management is expensive in terms of time and cost required to make necessary changes in the purpose of managing risk at the time of its occurrence. In contrast, proactive risk management provides information to stakeholders on how to best use resources to prevent the occurrence of unwanted events [11]. The latter aims at avoiding risks before they materialize; hence, it can be referred to as preventive risk management [16].

The best way to manage risks in e-Learning projects is to select the most suitable instructional design methodology and consider it during the development process as a mean to manage risks. Deciding upon the model that best fits a project is influenced by how risky the project is; the types of these risks and the degree to which each model supports risk management [17]. e-Learning projects are risky; they are vulnerable to several risks during the development and delivery phases. ADDIE (Analyze, Design, Develop, Implement and Evaluate) is the most popular well-known instructional design model. It is a prescriptive sequential instructional design model. Recently, opponents raise doubts around ADDIE model due to its strict linear implementation from the analysis phase to the evaluation [18]. Indeed, ADDIE e-Learning projects suffer from major risk factors that could not be handled using pure implementation of ADDIE. In ADDIE model, no feedback from stakeholders is incorporated until the last phase of the project [19]. Hence, the major risk factor is the late change in requirements. Any late change in requirements would either require a large amount of rework which would cost extra time and money [19], or it may lead to an unsatisfied user (i.e. low-quality process). Either case, project failure is inevitable. Another risk factor is that overlapping is not allowed, in other words, practitioners cannot move to the next phase until the previous phase is completely finished. Moreover, using ADDIE, no deliverables are made available to learners until the last phases of the project when all deliverables are ready [19]. Clearly, these factors will negatively affect the project especially if the project suffers from time contention. A recent trend is to abandon ADDIE and to move towards Agile approaches [9, 20]. Agile is a lean approach to project management that enables building releasable yet good quality products in short time periods [19]. Agile is an iterative [21], team-based, collaborative approach. At the end of each iteration, a working deliverable is made available to users, feedback from the users is sought at the end of each iteration and changes, if exist, are incorporated in successive iterations [22]. Moreover, iterations may overlap. Clearly, agile model avoids the major risks of the ADDIE model.

Risk management has not been extensively performed in eLearning projects [11]. In e-Learning, the project mainly passes through two phases; content development and learning delivery. Risks need to be managed carefully during both phases so that the project can achieve its expected outcomes. To achieve its outcomes, an e-Learning project should guarantees a high-quality content and a high- quality learning. Assuring this, the project surely leads to the major outcome of the learning process; high-quality student.

Implementing e-Learning in engineering education is challenging. Pedagogy, infrastructure, policy, strategy, quality, and management are the major challenges [23]. However, modern technologies have ushered in an era of change in engineering education [23]. In Engineering education, eLearning involves the use of ICT to deliver virtual classrooms, conducting laboratory experiments, administering Virtual Learning Environment (VLE), developing professional eContent that is rich in animations and visualizations that are used to demonstrate material, concepts, diagrams, processes, circuits, components and functioning [13]. However, an adequate application of e-Learning in engineering education would facilitate the learning process and lead to high quality learning.

Despite being a developing country, Jordan has made great strides in the fields of ICT but with a humbling experience in eLearning in HEIs. This is due to several barriers including resistance, technological infrastructure hinders, quality assurance issues and slow change of learning structures and processes. Hashemite University (HU) is a public university in Jordan. The experience of HU in e-Learning is not recent. However, all previous HU practices in e-Learning were blended learning; none of the offered courses were carried out fully online. Recently, HU started to recognize the importance of the fully online courses in reducing operating cost and 
increasing students' satisfaction especially with the economic challenges, resources constraints and the geographical location of the university [24]. With all these in mind, the quality of the outcomes of the fully online learning process has become a major priority of the university. Hence, the need to develop, deliver and evaluate a fully-online pilot course was a necessity. HU has started to move towards online courses and several eLearning projects have been started. HU intended to follow a quality framework in order to assure the quality of the eLearning process and the outcomes of the e-Courses.

However, the literature lacks such a process-oriented quality assurance framework. Hence, in this paper, we propose a process-oriented quality assurance framework to ensure the quality of an entire course. This framework is risk-oriented; it embeds a proactive risk management model for managing eLearning projects. According to the knowledge of the authors, the literature has not discussed how proactive risk management in e-Learning projects would enhance the quality of e-Learning courses. To validate this framework, a project was started in 2014 to develop and deliver a pilot course in Renewable Energy (RE). The course was first offered online in summer 2015-2016 then continuous piloting and monitoring were maintained over a period of 6 semesters. RE course was selected because it is a hot topic in Engineering, relatively advanced technical course, and never been developed and delivered electronically in the region.

This study aims at enhancing the quality of e-Learning in higher education by modelling and implementing proactive risk management in e-Learning projects. The main research issues that this paper aims to investigate are:

- To describe how proactive risk management can be implemented in e-Learning projects to enhance their quality.

- To identify the major risk factors associated with managing the implementation of an e-Learning project.

- To devise the major risk mitigation strategies associated with each risk factor.

- To compile a case study of an online course to collect and extract information about the applicability of eLearning at $\mathrm{HU}$.

- To describe how can we measure the quality of an eLearning course.

The rest of the paper is organized as follows: Section II reviews related work. Section III introduces the proposed framework, section IV introduces an implementation of the model through the RE course, section V displays, discusses and analyses the results of the RE course evaluation and presents some limitations of this work, and section VI concludes the work and suggests future work.

\section{RELATED WORK}

Several current projects and research aim at enhancing quality of e-Learning in HEIs. In [25], Bralić and Divjak proposed a blended learning model that integrates Massive Open Online Course (MOOC) into a traditional classroom. Their model was based on learning outcomes and used to evaluate the effectiveness of integrating a MOOC with classroom-based teaching. A model was proposed by Casanova and Moreira in [26] for teachers in HE to reflect and discuss the quality of Technology-Enhanced Learning (TEL) in their blended learning programs. They argued that HEIs need to be more critical with regard to the use of TEL, and to support it as a counterpart to traditional learning. The experience of the North Carolina Central University for an Introductory Biology course over four terms was discussed in [27]. In this research, Hollowell, Brooks, and Anderson discussed the impact of the application of quality course design standards on the design and student outcomes. Atoum, Al-Zoubi, Abu Jaber, AlDmour and Hammad [28] presented a new approach for delivering e-Learning courses in Jordanian universities. The researchers introduced a national quality assurance system for TEL that aims at improving, developing and implementing accreditation standards for quality assurance of TEL courses and study programs at a national level. English language course was implemented and delivered at a national level as a pilot study according to a strict quality assurance framework. In their project [5], Mazohl and Makl introduced scientific description of a practicable quality framework for blended learning. The proposed framework focuses on the quality of courses, the course itself, the quality in the organizations delivering blended learning courses, the learners' needs and the environmental conditions. Based on this framework, a pilot course was developed and tested at the University of Helsinki, Finland.

In [29], Gómez-Rey, Barbera and Fernández-Navarro explored the quality of the online learning experience based on the Sloan-C framework and the Online Learning Consortium's (OLC) quality scorecard. The researchers found that the OLC index has ignored the opinions of the learners in evaluating quality of online programs. Hence, they proposed an alternative way of measuring the quality of online learning programs using teachers and students' perceptions and satisfaction. Misut and Pribilova [6] proposed and verified a quality assurance method of e-Learning - ELQ based on Kirkpatrick model which includes four levels of evaluation: reaction, learning, behavior, and results. Ghislandi, Raffaghelli, and Yang [30] introduced an approach that takes into account the participants' engagement as insiders of a quality learning culture. In [31], Bremer described how the AKUE model could be used to improve the quality of eLearning and the eContent development. The AKUE model involves four phases: analysis, conception, implementation, and evaluation. In [32] Ossiannilsson and Landgren introduced a conceptual framework to enhance quality of e-Learning in $\mathrm{HE}$ based on experiences from three international benchmarking projects. The framework suggests that various aspects of accessibility, flexibility, interactivity, personalization, and productivity should be implemented at all levels in order to meet students' expectations. In [33] Lin and Chen reported that a successful e-Learning system should take both system and information quality into account. They combined Technology Acceptant Model (TAM) with Information system Success Model (ISM) by considering system quality, quality of platform information, and course information. Sarsa and Soler [34] studied the relations among the variables of e-Learning quality by means of five conceptual 
maps that ease the visualization of these relations. Marshall in [35] summarized the outcomes of multiple international eLearning Maturity Model (eMM) assessments which aimed at improving e-Learning quality in the organizations.

Very simple trials in the literature have discussed the role of risk management in e-Learning projects. Vesper, Kartog ${ }^{\complement} l u$, Herrington and Reeves [11] employed two risk assessment strategies in the formative evaluation of a task-based eLearning program developed by the World Health Organization (WHO). The first strategy used an expert reviewer and the second used a risk assessment expert facilitator. Both strategies aimed at identifying probable risks early and controlling them. Reference [36] examined the students' risk perception while using the aLF. The aLF is a LMS that was developed by Spanish National University of Distance Education (UNED), Vázquez-Cano and García found that risks are concentrated in two dimensions: "basic risks" and "own and beyond students' circumstances risks". Barik and Karforma [1] presented the risks that might face different eLearning system stakeholders. They also suggested tools and techniques to minimize those risks. The identified risks and techniques were related to integrity, security and reliability of an e-Learning system. In [3], Mahmud and Gope discussed several technological, psychological, socio-cultural and economic factors that would affect successful implementation of e-Learning in $\mathrm{HE}$ in Bangladesh. They concluded by recommending measures to resolve these issues with government and the private sectors.

In [37], Surcel and Reeiu presented a series of the problems of designing and implementing an e-Learning strategy, objectives, planning and didactic process management. They classified risks into risks associated to the professors and risks associated to the students. Finally, they proposed general controls to manage these risks. Allen and Hardin in [38] presented a model of management that encompasses the Instructional System Design (ISD) process. They also presented a process for evaluating the risk factors of the project and how to manage changes throughout the project that may threaten the project's success. Andersson [39] identified 37 major challenges for e-Learning in developing countries. The work used data from the eBIT program in the University of Colombo, Sri Lanka. These factors were discussed and solutions were suggested. Angelou and Economides in [40] presented a real-option methodology for controlling risks in eLearning infrastructure business field and choosing the optimum ICT investment's deployment strategy. In [12], Ifinedo investigated the risks associated with implementing an e-Learning information system project in Estonia. As a rankorder list of the typical project risk factors encountered in this project was produced.

Despite that HEIs have recently recognized the importance of e-Learning in engineering education; few attempts were found in the literature. Bandaya, Ahmed, and Jan [13] discussed the application of e-Learning in engineering education. The research investigates e-Learning practices in the
Engineering institutions of the state of Jammu and Kashmir as a case study. Rodríguez, Granados, and Muñoz [41] presented the intimate relationship between the e-Learning method and the studies of Engineering in Spain through teaching examples on several subjects of different Engineering studies. Benchicou, Aichouni and Nehari [42] reported the results of an empirical study that measures the readiness of HEIs in Algeria towards the application of the e-Learning in engineering education. An important barrier for implementing e-Learning in engineering education is the need for remote experimentations. Chandra and Samuel in [43] implemented a user-friendly system that allows students to carry out laboratory experiments from remote locations. Hence, despite the advent of e-Learning in all education fields, subtle improvements are required in the Engineering field.

In [44], Rooij and Williams stated that ADDIE is not enough for project management in instructional design and proposed research opportunities for closing the gap between instructional design education and practice.

\section{PROPOSED FRAMEWORK}

Recent research discusses the influence of Software Engineering methodologies and practices over instructional design methodologies to provide high quality e-Learning [9, $20,45,46,47]$. In this proposed framework, two Software Engineering concepts were combined with the instructional design methodology. These two concepts are Risk Management and Agility.

In this research, the authors propose a framework for eLearning projects that utilizes a proactive approach to risk management. Fig. 1 depicts an overview of the embedded model. This framework is risk-oriented wherein probable risks and risk factors are identified early and the whole development process is guided by the identified risks.

Typically, risk management process is integrated into the development and delivery process, and risks are avoided during the execution of the e-Learning process. In this framework, avoidance is imposed utilizing two aspects:

- First: adopting an instructional design model that best fits e-Learning projects

- Second: devising and implementing avoidance strategies that handle probable risk factors

In the proposed framework, a hybrid "Agiled-ADDIE" approach is used. Best practices from Agile is blended with ADDIE. e-Learning practitioners pass by all phases of ADDIE but with an order that is subject to continuous feedback from the different stakeholders. Using this approach, an effective collaboration and communication between all stakeholders, developers and learners is assured. This communication is the major constituent of Agile approach. The proposed framework consists of five stages: risk identification, planning, production, delivery and evaluation. These stages are: 
- Risk Identification: In order to implement a proactive risk management framework, risk factors should be identified early before proceeding into the actual eLearning development process. Hence, the first stage in this framework is risk identification stage. In this stage, the project manager sets a detailed list of risk factors that threaten the e-Learning project. This list is constructed based on project documentation, reviews of previous similar e-Learning projects, available checklists, and the project manager's experience. This initial list is refined later in the planning stage. Once the initial set of risk factors has been identified, they have to be managed. In this proactive framework, e-Learning practitioners proceed into the eContent development and delivery process phases, activities, risk mitigation strategies with an eye towards the identified risks and preventing them from being materialized [48].

- Planning: In this stage, the project is initialized; resources, risks and the course are planned. Team members are hired, tools are selected, budget and schedule are planned, sources of material are decided upon, and learners' analysis is carried on. The initial list of risk factors identified in the previous stage is refined here. Brainstorming sessions which involve all team members beside learners' analysis may come out with new important risk factors or may lessen the severity of any of the previously identified ones in the context of the project. Most importantly, a set of avoidance strategies is devised for each factor that mitigates the risk before being materialized. The devised strategies are practiced later in the proper phase of the project. Also, in this stage, the course objectives, outcomes, outlines and the assessment criteria are set. The organizational structure of the course and the basic unit of development (i.e. referred to as module) are also decided upon.

- Production: Developing eContent shares common aspects with software development, especially in the design and production stages [9]. Hence, Agility would be successful in this stage. The main goal of this method is to minimize the risk of incomplete or bad quality output. Using Agile, modules are produced iteratively. A module is produced at each iteration and enhanced in the successive iteration. Each module typically goes iteratively through the following phases:

- Design: In this phase, a set of learning objectives for each module besides the sequencing in which they should be achieved are formulated. The module outlines and the general look and feel of the module are created.

- Content preparation: In this phase, references and sources of information are selected, the material is collected and refined and the final content is written. The external support material may also be introduced.
- Storyboard design: A document is created in this phase that describes all elements of the final product including text elements, images, audio elements, animations, and interactions.

- Development: Interface layout and course outlines are created using the authoring tool. Media, interactive component, self-assessments, and quizzes are developed and then imported into the authoring tool.

- Publishing: The module is produced in a shareable format that can be handled by LMS in this phase.

- Review: The review in this phase is a formative assessment activity. Once the module is developed, and before it is delivered to the learners, a review should be conducted at the end of the iteration to ensure the quality of the module and continuous improvement. This review should mainly involve the Subject Matter Expert (SME) and the developer in order to make any required changes early in the successive iteration. Once the review has no negative feedback, then the module is ready to be delivered to the learner.

- Delivery: In this stage, the module is deployed into the LMS and made available to learners. This stage also includes managing and facilitating learners' activities such as virtual class-rooms, assignment, and quizzes. It is worth to mention that a module can be delivered even if others are not ready. This stage also includes quality assurance activities. During the delivery of each module, formative assessment is conducted. This assessment uses feedback from students during the learning process activities in order to evaluate the quality of the eContent, assess student's reception, improve weakness areas and strengthen the e-Learning course.

- Evaluation: Once all modules have been delivered and the course has finished, the course content and the instructional delivery should be evaluated. Feedback from students is used to perform the summative assessment. This assessment uses quantitative and qualitative analysis. Quantitative analysis uses students' satisfaction surveys to evaluate students' reaction towards the course and students' results and measure the knowledge they acquired through the course. Qualitative analysis uses interviews and open-ended questionnaires. The aim of the summative analysis at the end of the e-Learning course is to ensure that the course has achieved its expected outcomes and learning objectives and that the proposed risk management strategies have proven its effectiveness.

In real practice, the development stages described above remain applicable throughout all e-Content development projects. However, their differences emerge with regard to the anticipated project challenges and the proposed mitigation strategies. 


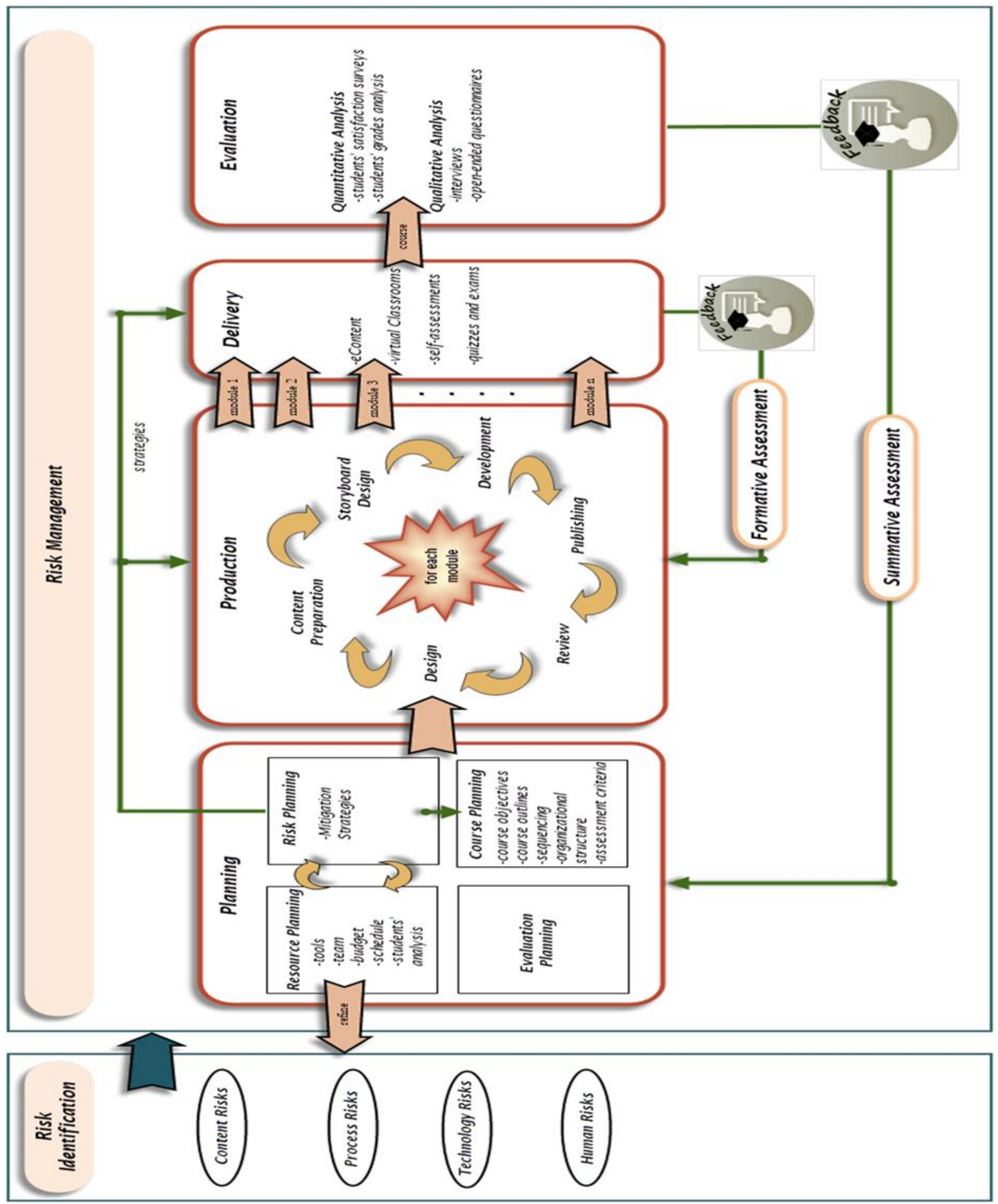

Fig. 1. The Proposed Proactive Risk Management Model for e-Learning Projects. 


\section{IMPLEMENTATION OF THE PROPOSED MODEL}

In order to validate the effectiveness of the proposed riskoriented quality assurance model, one pilot course in RE was designed and delivered at HU. Continuous piloting and monitoring of the course have been spanning over six semesters in purpose of examining the comprehension of students. The project started in early 2014 and was first delivered on summer 2015-2016. The intention of the project was to create an e-Content that could be used efficiently by $\mathrm{HU}$ students in the online RE course. The course included static content, media elements, animations and interactive components to help students understand course topics via activities such as e-Content packages, exercises, design problems, self-assessments, quizzes, online assignments, peer discussions and virtual classrooms. All of these activities were hosted at Moodle LMS.

The RE e-Course was initially created for the undergraduate Mechatronics Engineering students at HU. The sample of the study consisted of 186 undergraduate students distributed on six semesters as in Table I.

Using the risk management method described above, the project team members were able to systematically and proactively identify risks related to RE course and determine various ways to reduce their effects. Due to the risk-oriented nature of the framework, the team used the framework as dynamic rather than static approach. The process evolves as new risks arise and other risks disappear. The following subsections describe in details how the various stages of the model were implemented during the development and delivery of the RE course.

\section{A. Risk Identification Stage}

In this stage, the project manager identified the major sources of risk (i.e. risk factors) that are specific to the RE course. An initial list of risk factors was identified through brainstorming sessions that involved all stakeholders. This list was refined later in the planning stage. The identified risk factors were categorized into four categories. These categories are content, process, technology and human risks. Content risks are those factors that are related to the courseware preparation, design, and development. Process risks are the risks that are involved in the course delivery and learning process. Technology risks are related to technological infrastructure of the online educational system including both hardware and software issues. Human risks involve risks related to the end users of the e-Learning course (i.e. students and tutors). A final refined list of risk factors is displayed in Table II. In this list, 43 risk factors were identified and categorized into the four categories. Each factor was given a number that uniquely identifies it (i.e. Risk Identifier (RID)).

\section{B. Planning Stage}

In this stage, the planning covers four dimensions; risks, resources, course and evaluation planning.

Risk Planning: A set of mitigation strategies were devised for each of the identified risk factors. These strategies, listed in Tables III-XI were defined to be practiced later in the proper phases. The strategies were proposed after conducting brainstorming sessions that involved all project team members. Each member was asked to employ risk-based thinking and devise mitigation strategies that would be used to manage the previously defined risk factors. Moreover, these brainstorming sessions came out with new information about the already identified risk factors. As a result, a list of refined risk factors was produced as shown in Table II. These factors were the harvest of the project managers' experience, team members brainstorming sessions, and predefined ready-made checklist and taxonomies.

Resource planning: involved planning of team and roles, tools, students' analysis, budget and schedule, and divided into the following three aspects:

- Team Building: Team members were hired, roles were identified and assigned. The team involved and instructional designer (ID) who is responsible for defining the instructional, delivery and evaluation strategies, SME; the source of knowledge and responsible for content preparation, e-Content developer who is responsible for developing media components, assembling course elements and installing the courseware onto LMS, course administrator who manages learners accounts, online tutor who supports and motivates students learning activities during the course, and a technical support specialist who provides technical support for all stakeholders during all phases.

- Technology Tools: A decision was made about the tools needed to be used to create and deliver the e-Learning content. We used Adobe Photoshop for creating bitmap images, Adobe Illustrator for vectoral images, Adobe Flash for creating animations, Trivantis Lectora as an authoring tool, Sony Sound Forge for sound file editing, Moodle as a LMS, SQL Server as a Database Management System (DBMS), Google forms for conducting surveys, Microsoft (MS) PowerPoint for making presentations and MS Word for creating tutorials and documents.

- Students Analysis: Students come to the course with different backgrounds, abilities and varying levels of understanding, computer skills and technical experience. Hence, the course should be designed in a way that satisfies the needs of all these students. Moreover, analyzing students' backgrounds may reveal new risk factors that could threaten the development process, or lessen the severity of other factors. For these purposes, a pre-survey was conducted in the planning phase. The results and the detailed analysis of the presurvey are introduced in the following section.

TABLE I. SAMPLE DISTRIBUTION

\begin{tabular}{|l|l|}
\hline Semester & Enrolled students \\
\hline Summer 2015-2016 & 24 \\
\hline First 2016-2017 & 30 \\
\hline Second 2016-2017 & 31 \\
\hline Summer I 2016-2017 & 40 \\
\hline Summer II 2016-2017 & 28 \\
\hline First 2017-2018 & 33 \\
\hline
\end{tabular}


TABLE II. RE COURSE PROJECT RISK FACTORS

\begin{tabular}{|c|c|c|}
\hline Category & RID & Risk Factor Description \\
\hline \multirow{18}{*}{ 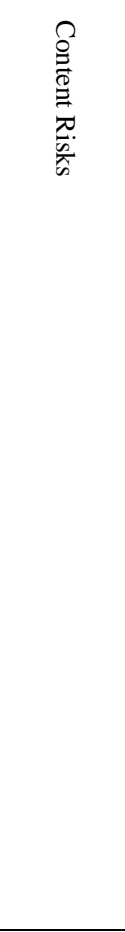 } & 1 & Course is difficult to navigate \\
\hline & 2 & Course is unusable \\
\hline & 3 & Content is inaccessible \\
\hline & 4 & Content is rigid and not interesting \\
\hline & 5 & Course is not visually attractive \\
\hline & 6 & Lack of interactivity \\
\hline & 7 & $\begin{array}{l}\text { Difficulties to work with several types of media } \\
\text { content }\end{array}$ \\
\hline & 8 & Requirements change \\
\hline & 9 & Inadequate educational resources \\
\hline & 10 & Low quality media content \\
\hline & 11 & Loading delay \\
\hline & 12 & Lack of consistency \\
\hline & 13 & Low quality content \\
\hline & 14 & Course structure is not understandable \\
\hline & 15 & Content is difficult to understand \\
\hline & 16 & $\begin{array}{l}\text { Student cannot identify what should he know from } \\
\text { each module }\end{array}$ \\
\hline & 17 & Use of foreign language \\
\hline & 18 & $\begin{array}{l}\text { Content developers are not familiar with the content } \\
\text { domain }\end{array}$ \\
\hline \multirow{14}{*}{ 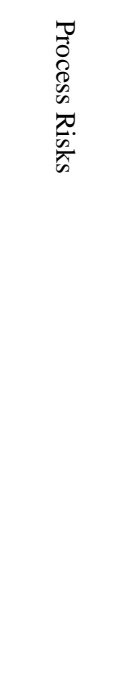 } & 19 & Content cannot be deployed into LMS successfully \\
\hline & 20 & Timing and sequencing of activities are unclear \\
\hline & 21 & $\begin{array}{l}\text { Course does not fulfill its stated objectives and } \\
\text { learning outcomes }\end{array}$ \\
\hline & 22 & Inadequate assessment \\
\hline & 23 & Unclear assessment policy \\
\hline & 24 & Violation of assessment procedures \\
\hline & 25 & Lack of direct face to face interaction with the tutor \\
\hline & 26 & Students miss collaborative work \\
\hline & 27 & Miscommunication between team members \\
\hline & 28 & Delivery delay \\
\hline & 29 & Poor technical assistance \\
\hline & 30 & Unauthorized access \\
\hline & 31 & Violation of law \\
\hline & 32 & Students are confused about what and how to learn. \\
\hline \multirow{6}{*}{ 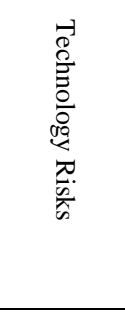 } & 33 & Problems in Internet connection \\
\hline & 34 & $\begin{array}{l}\text { Unreliable technical, hardware and software } \\
\text { infrastructure }\end{array}$ \\
\hline & 35 & Browser incompatibility \\
\hline & 36 & Large number of concurrent connections to server \\
\hline & 37 & Student does not have computers \\
\hline & 38 & Update and upgrade risks \\
\hline \multirow{5}{*}{ 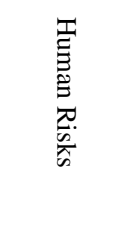 } & 39 & Tutor is inexperienced in e-Learning technologies \\
\hline & 40 & Tutor's resistance to online learning \\
\hline & 41 & Students' resistance to online learning \\
\hline & 42 & Students lack the required computer skills \\
\hline & 43 & Non-interactive tutor \\
\hline
\end{tabular}

Course Planning: In course planning, high level objectives, course outlines, organizational structure, and assessment criteria were defined. The organizational structure of the RE course was hierarchal. The e-Content was composed of seven topics. The "Topic" is considered the basic unit of development. These Topics are: Introduction to RE, Photovoltaic Systems, Hydropower Energy, Geothermal Energy, Solar Thermal Energy, Wind Energy and Energy Economics. All topics are organized in similar ways. Each Topic is divided into sections and each section is divided into lessons. In order to evaluate students' knowledge and understanding of the material, it was agreed upon post assessment quizzes after each topic, mid-term and final exam. In addition, design projects were carried out online.

Evaluation Planning: It was decided to use both formative and summative assessments. Formative assessment was planned to be achieved through reviews conducted in the production phase and through feedback from students during the learning activities in order to collect information for the purpose of improving the e-Learning material being delivered. Summative assessment was decided to be at the end of the course in order to measure the effectiveness of the e-Learning process and the proposed framework. Most studies rely on user satisfaction or the acquired knowledge (or both) in order to evaluate an e-Learning process [49]. In this study, we use students satisfaction surveys at the end of the semester to find out how satisfied they are in the course and to make improvements based on their feedback. Moreover, students' final grades are analyzed at the end of the semester in order to measure the quality of the results and the acquired knowledge. Student's final grades consist of midterm and final exams in addition to the quizzes and projects taken during the course.

During each activity in each phase, the set of the mitigation strategies proposed in the planning phase are practiced cautiously by team members based on their roles in order to mitigate the negative effects of the corresponding identified risk factors. Lists of mitigation strategies to be practiced in each phase are introduced in Tables III-XI. Each strategy is uniquely defined using a strategy identifier (SID). Beside each of the identified strategies, the target risk factors IDs (TRIDs) that aim to mitigate are indicated.

For planning phase, a list of the proposed mitigation strategies involved in the planning phase is displayed in Table III.

\section{Production Stage}

The actual implementation of the e-Content was carried out at this stage. The development of the e-Content was accomplished module by module. Agile development was a major risk mitigation strategy to avoid requirements change and delivery delay risks as appears in Table IV. According to the framework, each module iteratively passed by 6 phases; design, content preparation, storyboard design, development, publishing, and review. The first phase of the production stage is the module design. A set of mitigation strategies were suggested in this phase in order to mitigate risk factors, these strategies are displayed in Table V. Once the module was designed, content preparation started. Several risk mitigation strategies were followed whilst preparing content in order to 
mitigate risk factors. These strategies are depicted in Table VI. Creating storyboards is very important; they are themselves a mitigation strategy. The creation process also involves several risk mitigation strategies. These strategies are displayed in Table VII. In the development phase, the actual implementation of the courseware was carried on. The majority of content risks could be avoided by following several risk management strategies in this phase. These strategies are displayed in Table VIII. In the publishing phase, modules are produced in a shareable format to be handled by the LMS. The strategies that could be followed are displayed in Table IX. The last phase in the production is to test the courseware module and review it before it is delivered to students. The strategies that could be followed in this phase are displayed in Table X.

TABLE III. Risk Mitigation StRATEgIES IN THE PlanNing Stage

\begin{tabular}{|l|l|l|}
\hline SID & Strategy & TRID \\
\hline S1 & Allocate a variety of software and development kit & 7 \\
\hline S2 & $\begin{array}{l}\text { Ensure that the choice of software tools can easily support } \\
\text { different file and media formats }\end{array}$ & 7 \\
\hline S3 & Use courseware authoring tool & 7 \\
\hline S4 & All tools are licensed & 31 \\
\hline S5 & $\begin{array}{l}\text { Hire professional media specialists (graphic designer, } \\
\text { animator) }\end{array}$ & 7 \\
\hline S6 & Team members are selected from university (insource) & 27 \\
\hline S7 & $\begin{array}{l}\text { Leverage talents from the organization (i.e. university } \\
\text { students) to help in developing media content }\end{array}$ & 7 \\
\hline S8 & $\begin{array}{l}\text { Select a tutor with good computer skills and comfortable } \\
\text { working online with students }\end{array}$ & 39,43 \\
\hline S9 & $\begin{array}{l}\text { Provide training on how to make the best use of online } \\
\text { facilities for e-Learning support }\end{array}$ & 39,40, \\
\hline S10 & Training sessions on multimedia development & 7 \\
\hline S11 & $\begin{array}{l}\text { Impose computer skills classes as a prerequisite for the } \\
\text { course }\end{array}$ & 42 \\
\hline S12 & Breaking course into several modules (modular structure) & 8 \\
\hline S13 & Describe the general organizational structure of the course & 14 \\
\hline S14 & Assessment procedure is determined early in this phase & 23 \\
\hline S15 & $\begin{array}{l}\text { Mid and final summative exams were decided upon as } \\
\text { formal Assessment }\end{array}$ & 22 \\
\hline S16 & $\begin{array}{l}\text { Quizzes are suggested to be used as part of the formal } \\
\text { assessment process }\end{array}$ & 22 \\
\hline
\end{tabular}

TABLE IV. Risk Mitigation Strategies in the Production Stage

\begin{tabular}{|l|l|l|}
\hline SID & Strategy & TRID \\
\hline S17 & Agile development & 8,28 \\
\hline
\end{tabular}

TABLE V. Risk Mitigation Strategies in the Production Stage DESIGN PHASE

\begin{tabular}{|c|l|c|}
\hline SID & \multicolumn{1}{|c|}{ Strategy } & TRID \\
\hline S18 & Objectives and outlines are identified before each module & 16,32 \\
\hline S19 & $\begin{array}{l}\text { Objectives of the module should match the expected course } \\
\text { outcomes }\end{array}$ & 21 \\
\hline S20 & Include a short description for each module & 16 \\
\hline S21 & Pre-quiz is selected as an evaluation strategy & 16 \\
\hline S22 & Self-assessment is selected as an evaluation strategy & 21 \\
\hline S23 & post-quiz is selected as an evaluation strategy & 21 \\
\hline
\end{tabular}

TABLE VI. Risk Mitigation StRategies in the Production STAGE CONTENT PREPARATION PHASE

\begin{tabular}{|l|l|l|}
\hline SID & Strategy & TRID \\
\hline S24 & Instructional content relates directly to objectives & 21 \\
\hline S25 & Select material from high-quality textbooks and articles & 9 \\
\hline S26 & $\begin{array}{l}\text { Use internal social media network to ask around for } \\
\text { resource material }\end{array}$ & 9 \\
\hline
\end{tabular}

\begin{tabular}{|l|l|l|}
\hline S27 & Provide links to extra material & 9,15 \\
\hline S28 & Keep paragraphs short & 5,15 \\
\hline S29 & Use common formal language "i.e. English" & 17 \\
\hline S30 & Use simplest words and elaborations & 15,17 \\
\hline S31 & Integrate real-life examples and problems into the course & 5,15 \\
\hline S32 & There is a summary at the end of each module & 16 \\
\hline S33 & Glossary is used to define key terms and abbreviations & 16 \\
\hline
\end{tabular}

TABLE VII. Risk Mitigation Strategies IN THE PRODUCtion STAGE STORYBOARD DESIGN PHASE

\begin{tabular}{|l|l|l|}
\hline SID & Strategy & TRID \\
\hline S34 & $\begin{array}{l}\text { Script is prepared jointly (i.e. content provider and content } \\
\text { developer) }\end{array}$ & 13,18 \\
\hline S35 & $\begin{array}{l}\text { Script describes the organizational structure of the module } \\
\text { and exact table of contents }\end{array}$ & 1,14 \\
\hline S36 & $\begin{array}{l}\text { Script should describe in detail media elements and desired } \\
\text { interactions }\end{array}$ & 13 \\
\hline S37 & $\begin{array}{l}\text { Do not include more than two paragraphs or 7 bullets items } \\
\text { to a page. }\end{array}$ & 5,15 \\
\hline S38 & $\begin{array}{l}\text { Use bullets, tables, callouts, interspersed images to organize } \\
\text { concepts }\end{array}$ & $15,4,5$ \\
\hline S39 & Punctuation and capitalizations are used appropriately & 13 \\
\hline S40 & Avoid monolithic: chunk information into small pieces & 15 \\
\hline S41 & Rely on the power of interactivity & 15,6 \\
\hline S42 & $\begin{array}{l}\text { Employ humour to emphasize a point in relevant, light- } \\
\text { hearted way }\end{array}$ & 4 \\
\hline S43 & Script lesson is proofread in terms of content by SME & 13 \\
\hline S44 & $\begin{array}{l}\text { Script lesson is proofread in terms of language by language } \\
\text { editor and word processor }\end{array}$ & 13 \\
\hline
\end{tabular}

TABLE VIII. Risk Mitigation StRategies IN the Production Stage DEVELOPMENT PHASE

\begin{tabular}{|l|l|l|}
\hline SID & Strategy & TRID \\
\hline S45 & $\begin{array}{l}\text { The eContent design allow student to pause and resume } \\
\text { the course without losing their place }\end{array}$ & 1 \\
\hline S46 & $\begin{array}{l}\text { Animations and navigational elements does not distract } \\
\text { focus of attention }\end{array}$ & 1 \\
\hline S47 & Hyperlinks are clearly identified. & 1 \\
\hline S48 & $\begin{array}{l}\text { All hyperlinks work and direct the student to the proper } \\
\text { location }\end{array}$ & 1 \\
\hline S49 & $\begin{array}{l}\text { Only reasonable hyperlinks and navigation elements are } \\
\text { provided (students are not overwhelmed with hyperlinks) }\end{array}$ & 1 \\
\hline S50 & $\begin{array}{l}\text { Hyperlinks are not introduced early at paragraphs need to } \\
\text { be read completely or near important points. }\end{array}$ & 1 \\
\hline S51 & $\begin{array}{l}\text { Navigation is allowed using "back" and "forward" } \\
\text { buttons, table of contents, and navigation path. }\end{array}$ & 1 \\
\hline S52 & $\begin{array}{l}\text { Navigation buttons are easily identifiable, and perceive a } \\
\text { good level of affordance }\end{array}$ & 1 \\
\hline S53 & $\begin{array}{l}\text { At any time student can identify his location with respect } \\
\text { to course using a navigation path }\end{array}$ & 1 \\
\hline S54 & $\begin{array}{l}\text { Develop a course map that enables student get an at-a- } \\
\text { glance view of course content }\end{array}$ & 1 \\
\hline S55 & $\begin{array}{l}\text { Clear instructions are designed to prevent possible } \\
\text { runtime errors }\end{array}$ & 2 \\
\hline S56 & Course layout inspires student what to do in each page & 2 \\
\hline S57 & $\begin{array}{l}\text { e-Learning activities are labelled and numbered in a way } \\
\text { guides learners through the course. }\end{array}$ & 1,2 \\
\hline S58 & $\begin{array}{l}\text { Error messages and direction are expressed in } \\
\text { understandable language }\end{array}$ & 2 \\
\hline S59 & $\begin{array}{l}\text { Needed information is provided on the same screen to } \\
\text { minimize recall }\end{array}$ & 2 \\
\hline S60 & Horizontal and vertical scrolling is avoided & 2 \\
\hline S61 & Use icons related to actions & 3 \\
\hline S62 & $\begin{array}{l}\text { Avoid colour combinations that are problematic for } \\
\text { colour blind people }\end{array}$ \\
\hline S63 & Use large enough thick fonts & 3 \\
\hline S64 & $\begin{array}{l}\text { Combine sound narration to highlight certain points or to } \\
\text { provide certain comments on animations }\end{array}$ \\
\hline
\end{tabular}




\begin{tabular}{|c|c|c|}
\hline S65 & Use Alt tags to describe images & 3 \\
\hline S66 & Text is provided for all non-text elements & 3 \\
\hline S67 & Use Font colours visible against background colour & 3,5 \\
\hline S68 & $\begin{array}{l}\text { (i.e. Main body text uses black font against white } \\
\text { background) }\end{array}$ & 3 \\
\hline S69 & Main body text uses Sanserif font (i.e. Verdana) & 3 \\
\hline S70 & $\begin{array}{l}\text { Avoid unnecessary colours, instead use bold and italic to } \\
\text { emphasize }\end{array}$ & 3 \\
\hline S71 & Use appropriate line spacing & 3 \\
\hline S72 & Use play/pause to control sound & $4,5,15$ \\
\hline S73 & $\begin{array}{l}\text { Incorporate various types of multimedia (text, graphics, } \\
\text { audio, video animations) }\end{array}$ & 4 \\
\hline S74 & Employ narrative storytelling & 4 \\
\hline S75 & Use appealing, simple, informative and helpful voice & 4,5 \\
\hline S76 & Use bullets, tables, callouts, interspersed images & 4,6 \\
\hline S77 & $\begin{array}{l}\text { Use thought-bubble callouts that appeared alongside our } \\
\text { content with characters' faces }\end{array}$ & 5 \\
\hline S78 & Balance between text and graphics & 5,12 \\
\hline S79 & Use decorative fonts only for headings & 5 \\
\hline S80 & Paragraph are justified & 4,6 \\
\hline S81 & Include quizzes with feedback at the end of each module & 6 \\
\hline S82 & Use of animations, navigations, and learning objects. & 6 \\
\hline S83 & Use of interactive infographics & 10 \\
\hline S84 & Sound files are recorded and edited in .wav format & $10,11,33$ \\
\hline S85 & $\begin{array}{l}\text { Use PNG format for images (i.e. lossless data } \\
\text { compression format) }\end{array}$ & 10 \\
\hline S86 & Most animations have framerate of $24 \mathrm{fps}$ & 3 \\
\hline S87 & No animations faster than $30 \mathrm{fps}$ & 10 \\
\hline S88 & $\begin{array}{l}\text { Animations narration sound files compressed as speech } \\
22 \mathrm{kHz}\end{array}$ & 10 \\
\hline S89 & Animations use lossless compression PNG images & 10 \\
\hline S90 & Use text to speech software & 12 \\
\hline S91 & $\begin{array}{l}\text { Use the same voice through different modalities such as } \\
\text { videos, animations, infographics, text, etc. }\end{array}$ & 12 \\
\hline S92 & Each module has the same layout & 12 \\
\hline S93 & $\begin{array}{l}\text { Keep fonts types and formats consistent through the } \\
\text { course }\end{array}$ & 12 \\
\hline S94 & Do not use more than 3 fonts & 12 \\
\hline S95 & Overall design is uniformed & 12 \\
\hline S96 & Colours are used consistently & 12 \\
\hline S97 & Navigation is consistent throughout the course & 12 \\
\hline S98 & $\begin{array}{l}\text { Animations and videos are consistent in quality, size and } \\
\text { type }\end{array}$ & 12 \\
\hline S99 & Images are consistent in quality, size and type & 31 \\
\hline S100 & References are stated at the end of each topic & 31 \\
\hline S101 & Graphics, videos, animations, books copyrights reserved & 33 \\
\hline S102 & Make e-Learning content smaller & 33 \\
\hline S103 & $\begin{array}{l}\text { Videos and images that require a high speed Internet are } \\
\text { avoided }\end{array}$ & 33 \\
\hline
\end{tabular}

TABLE IX. Risk Mitigation Strategies in the Production Stage PUBLISHING PHASE

\begin{tabular}{|l|l|l|}
\hline SID & Strategy & TRID \\
\hline S104 & $\begin{array}{l}\text { Publish module into sharable content object reference } \\
\text { model (SCORM) format }\end{array}$ & 19 \\
\hline S105 & Publish illustration videos onto a YouTube channel & 15 \\
\hline
\end{tabular}

TABLE X. Risk Mitigation StRategies in the Production STAGE REVIEW PHASE

\begin{tabular}{|l|l|l|}
\hline SID & Strategy & TRID \\
\hline S106 & Involve the SME and the developer in the review & 13 \\
\hline S107 & Test the content on different mobile devices & 3 \\
\hline S108 & Test the content on the most common browsers & 35 \\
\hline S109 & Testing was done with a student account & 3,30 \\
\hline S110 & All combinations of assessments were tested & 22 \\
\hline
\end{tabular}

\section{Delivery Stage}

In the delivery stage, e-Content modules are made available to the learners and the learning process takes place. The list of strategies that could be followed to handle risk factors (mainly process factors) is described in Table XI.

TABLE XI. Risk Mitigation STRATEGIES IN THE DELIVERY STAGE

\begin{tabular}{|c|c|c|}
\hline SID & Strategy & TRID \\
\hline S111 & $\begin{array}{l}\text { A help video was produced and its link is included on the } \\
\text { main page. }\end{array}$ & 1,2 \\
\hline S112 & Hardware and software requirements are identified early & 3,37 \\
\hline S113 & $\begin{array}{l}\text { Direct download links are provided for the required } \\
\text { plugins (PDF reader, SWF player) }\end{array}$ & 3 \\
\hline S114 & Design a study guide and course syllabus & 20 \\
\hline S115 & $\begin{array}{l}\text { Identify mandatory assignments and submission dates } \\
\text { early }\end{array}$ & 20 \\
\hline S116 & Each module is given a sufficient time in the syllabus & 20 \\
\hline S117 & Feedback from students are sought periodically & 21 \\
\hline S118 & Assessment includes several types of questions & 22 \\
\hline S119 & Feedback is given for each question & 22 \\
\hline S120 & Assessments were challenging and realistic & 22 \\
\hline S121 & Every learning objective is assessed & 22 \\
\hline S122 & Exams, quizzes, graded assignments are clarified early & 23 \\
\hline S123 & Exams and quizzes were held online but not distant & 24 \\
\hline S124 & $\begin{array}{l}\text { Exams and quizzes held at university lab (broadband } \\
\text { connection) }\end{array}$ & 33 \\
\hline S125 & Quizzes questions and choices (if there is) were shuffled & 24 \\
\hline S126 & Quizzes and exams had "start and end time" & 24 \\
\hline S127 & $\begin{array}{l}\text { Student names and login information are imported from } \\
\text { university registration systems }\end{array}$ & 24 \\
\hline S128 & $\begin{array}{l}\text { Conduct virtual office hours using synchronous tools (i.e. } \\
\text { chat rooms, instant messaging) }\end{array}$ & $\begin{array}{l}4,6,25, \\
26\end{array}$ \\
\hline S129 & $\begin{array}{l}\text { Use asynchronous communication tools (i.e. email, } \\
\text { forums, social networks groups) }\end{array}$ & $\begin{array}{l}4,6,25, \\
26\end{array}$ \\
\hline S130 & $\begin{array}{l}\text { Bulletin board is used for general announcements from } \\
\text { instructors }\end{array}$ & 25 \\
\hline S131 & $\begin{array}{l}\text { Assignments are submitted and graded with tutor } \\
\text { feedback via Moodle }\end{array}$ & 25 \\
\hline S132 & $\begin{array}{l}\text { Tutors are given administrative privileges regarding } \\
\text { content management. }\end{array}$ & 29 \\
\hline S133 & $\begin{array}{l}\text { Contact information of the technical support is given to } \\
\text { both tutors and students }\end{array}$ & 29 \\
\hline S134 & $\begin{array}{l}\text { Assign a separate topic in the discussion forum for } \\
\text { reporting on technical problems }\end{array}$ & 29 \\
\hline S135 & Accounts were set carefully with privileges based on roles & 30 \\
\hline S136 & $\begin{array}{l}\text { Only registered students are enrolled and can access the } \\
\text { course }\end{array}$ & 30 \\
\hline S137 & Once the course is finished, all enrolment are cancelled & 30 \\
\hline S138 & Use firewall to control access & 30 \\
\hline S139 & References are stated at the end of each topic & 31 \\
\hline S140 & Assign a tutor that facilitates the learning process & 32 \\
\hline S141 & Technical assistance team & 32 \\
\hline S142 & $\begin{array}{l}\text { Configure the maximum worker threads server } \\
\text { configuration option }\end{array}$ & 36 \\
\hline S143 & $\begin{array}{l}\text { Guarantee the availability of services using redundant } \\
\text { Moodle server }\end{array}$ & 34 \\
\hline S144 & $\begin{array}{l}\text { Regular data backups are taken from the course in case of } \\
\text { a breakdown of certain components }\end{array}$ & 34 \\
\hline S145 & $\begin{array}{l}\text { A high technical specification lab is dedicated to course } \\
\text { access }\end{array}$ & 34,37 \\
\hline S146 & Regular backup of the course & 38 \\
\hline S147 & Avoid updates or upgrades at critical times & 38 \\
\hline S148 & The version of the course is indicated & 38 \\
\hline S149 & Orientation day to motivate students to online learning & 41,42 \\
\hline
\end{tabular}




\section{E. Evaluation Stage}

Evaluation should be done at all stages; before the start date of the course, during the delivery, and after its completion. The post-course evaluation (i.e. summative evaluation) is the most important and the most challenging one. It is achieved by conducting a comprehensive survey at end of the course.

\section{- Satisfaction Survey}

At the end of the course, feedback from all project stakeholders was sought. The evaluation was conducted on two types of users, namely students and development team. Being the focal aspect of the e-Learning process, students' feedback is given a high concentration in the evaluation process. Students' feedback is very important. Throughout this feedback, students can describe their learning experience in the course. They can describe the content, material, activities, course design, delivery process, assessment methodology, etc. From their comments, pros and cons of the course are revealed so that they can be considered in the future to improve the design, deliverables and the delivery of the course. Herein, student's satisfaction surveys were used; a questionnaire-based approach that relies solely on students and how they were satisfied with the course. In this context, the main purpose of this questionnaire was to measure how the proposed framework and more specifically the proposed risk management strategies were effective in mitigating the identified risks. It was believed that if students exhibit high satisfaction towards the different course components, then the risk factors had been successfully managed by the proposed framework. Moreover, this questionnaire highly supports the internal quality assurance mechanism used at HU.

As mentioned before, post-course evaluation is the most challenging. This could be ascribed to two reasons. First, this survey should be comprehensive in a way that covers all key aspects of both design and delivery processes. The second is that this comprehensive nature of the survey would result in a quite lengthy survey that overwhelms students. In order to overcome these barriers and to encourage students to react to survey, the questionnaire was conducted online (using Google Forms) at the end of each semester. The questionnaire consists of 38 5-Likert scale questions ( 1 = Strongly Disagree, $2=$ Disagree, $3=$ Neutral, $4=$ Agree, and $5=$ Strongly Agree). The questions are formulated in a way that covers all risk categories and factors. The scale consisted of four subscales that measure course content, learning process, technology use, and people involved. Each question corresponds to one or more risk factors and measures whether each of these risk factors was mitigated well.

In purpose of evaluating students' satisfaction, the arithmetic mean score was used. The mean is the average of all responses for each item. The mean is often used to report central tendency of Likert items. It gives the best overall statistic of the typical rating given by survey respondents since it takes all data into account [50]. Mean score values above 4 are considered strong, between 3.5 and 4 are considered solid, and scores below 3.5 should be of concern [51]. Moreover, to measure the variability of students' responses, the standard deviation for each item was calculated. An item with a standard deviation greater than 1 indicates a wide variety in students' responses [51].

In order to ensure the comprehensive and the assimilation of students, the questionnaire was conducted among the students at the end of each semester to find out how satisfied they were in the course. Students' responses in all semesters are analyzed in the following section.

\section{- Grades Analysis}

It was believed that without measuring learning effectiveness, the quality of the e-Content and the e-Learning process could not be evaluated. Students' results and their grades were used as indicators of learning effectiveness and indicate the level of student achievement in the course. Student's final grades were drawn electronically from the university registration system. It consisted of the midterm, final exams, quizzes, and projects/assignments taken during the course. Exams and quizzes were administered to consist of good quality question items that cover all learning outcomes defined in the course. Moreover, information obtained from this evaluation can be used to enhance the pedagogical quality of the content.

\section{RESUlTS, ANALYSIS AND DiSCUSSION}

In this section, the results of the pre-survey that aimed at identifying new risk factors related to students or updating the severity of the already defined ones are introduced in details. More important, the effectiveness of the proposed framework in developing and delivering high quality e-Learning is verified based on satisfaction surveys and grades analysis. The results of implementing the framework in developing and delivering RE course in six semesters during the period 2015-2017 are introduced.

\section{A. Pre-Survey}

Students backgrounds were analyzed through a pre-survey that aimed at identifying other risk factors related to the learners. The pre-survey was conducted online and made available to the students via LMS. The pre-survey targeted a random sample of the Mechatronics Engineering students from different levels. A total number of 121 responses were collected. The pre-survey covered five dimensions: language and technical skills, e-Learning experience, feelings and doubts, hardware and software platforms, and disabilities.

Fig. 2 exhibits students' backgrounds and skills. When questioned about their fluency in English only 55 students $(45.45 \%)$ said that they are fluent in English. This percentage would emphasize the "use of foreign language" risk factor. Regarding computer literacy, 83 students (68.60\%) acknowledged that they have good computer skills. This fair percentage would also emphasize the risk factor "Students lack the required computer skills". A total number of 75 students $(61.98 \%)$ used to access information from the web, 85 students $(70.25 \%)$ feel at ease with online technology, 55 students (45.45\%) used to use forums, and 52 students $(42.98 \%)$ used to participate in chat rooms. The relatively low percentage of using forums and chat rooms would negatively affect students' interaction with the tutor and other students through the synchronous and asynchronous communication mechanisms. 
Students were asked if they already had any e-Learning experience before, Fig. 3. Only 15 students (12.40\%) enrolled full online course. More specifically, 48 students $(39.67 \%)$ used forums in other courses, 39 students (32.23\%) used chatrooms, 56 students $(46.28 \%)$ practiced self-assessment program, 80 students $(66.12 \%)$ practiced online exams, and 52 students $(42.98 \%)$ used VLE to download material and resources. Overall, most e-Learning activities are practiced with a low percentage (excluding online exams) as appears in Fig. 3. This would negatively affect students' usage of course activities. Regarding VLE, 100 students (82.64\%) had used Moodle VLE, and only 21 students (17.36\%) had used a VLE other than Moodle. Hence, a decision was made to adopt Moodle as a VLE for this course.

Students also were asked about their feelings, doubts, and worries about the course, Fig. 4. A total number of 28 students $(23.14 \%)$ preferred to take this course in a traditional classroom than totally online, 35 students $(28.93 \%)$ were uncertain and 58 students $(47.93 \%)$ preferred online delivery. From this, we can conclude that still there is some resistance from students towards online learning (i.e. risk factor). Deeply, 31 students $(25.62 \%)$ were worried about the absence of the face-to-face tutor, 42 students $(34.71 \%)$ were uncertain and 48 students $(39.67 \%$ ) had no worries about this issue (another risk factor). 29 students $(23.97 \%)$ were worried about being isolated from other colleagues, 23 students (19.01\%) were uncertain and 69 students $(57.02 \%)$ were not worried. This fair percentage could be ascribed to the various currently available communication technologies which make this factor less severe. Moreover, 45 students $(37.19 \%)$ were worried about the assessments and grading policy, 35 students (28.93\%) were uncertain and 20 students $(33.88 \%)$ had no worries. This would increase the importance of mitigating this risk factor.

Additionally, students were questioned about the hardware and software platform they have, Fig. 5. A total number of 115 students $(95.04 \%)$ students have personal computers. This high percentage would eliminate this risk factor. Moreover, $51(44.35 \%)$ have windows 7 installed, 12 students $(10.43 \%)$ have windows 8,42 students $(36.52 \%)$ have windows 10 , and 10 students $(8.70 \%)$ have other operating systems. Also, 40 students $(34.78 \%)$ have 1-2 GB RAM and 75 students $(65.22 \%)$ have RAMs larger than 2GB. Small size RAMs may negatively affect course navigation, delay playing media content, etc. 97 students $(84.35 \%)$ uses Chrome browser, 5 students $(4.35 \%)$ IE and 7 students $(6.09 \%)$ Firefox and 6 students $(5.22 \%)$ used other browsers. Accordingly, students use different Internet Browsers; browsers incompatibility is another risk factor. Regarding plugins, 109 students (94.78\%) have a PDF reader installed on their pcs, and 55 students $(47.83 \%)$ have a SWF player installed. This might prevent the student from playing animations and other media contents (i.e. risk factor). With respect to the Internet connection, 103 students $(85.12 \%)$ have Internet connection 24/7. Among them, 28 students $(27.18 \%$ ) have up to $2 \mathrm{Mbps}$ Internet connection, 49 students $(47.57 \%)$ have up to $8 \mathrm{Mbps}$ and 26 students (25.24\%) has up to $16 \mathrm{Mbps}$. Problems in connection is a risk factor. Moreover, Low connection speed may cause loading delay (another risk factor).

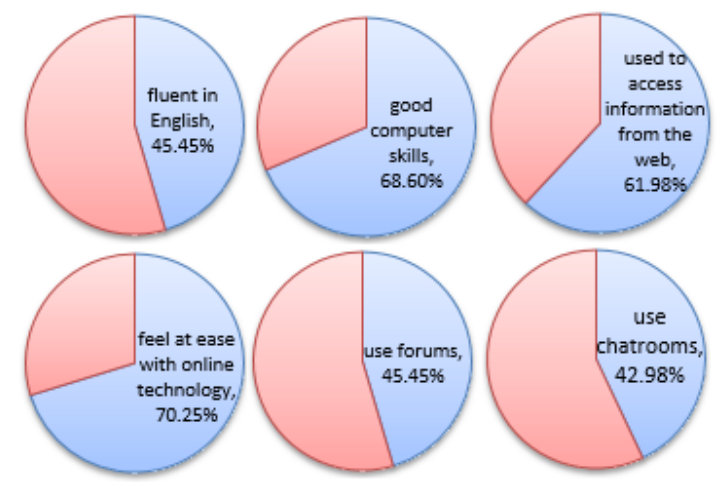

Fig. 2. Students' Backgrounds and Skills.

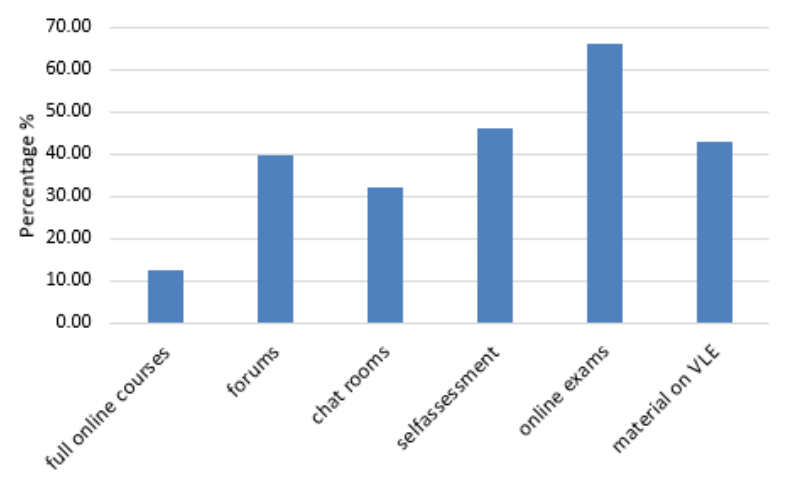

Fig. 3. Students' e-Learning Experience.

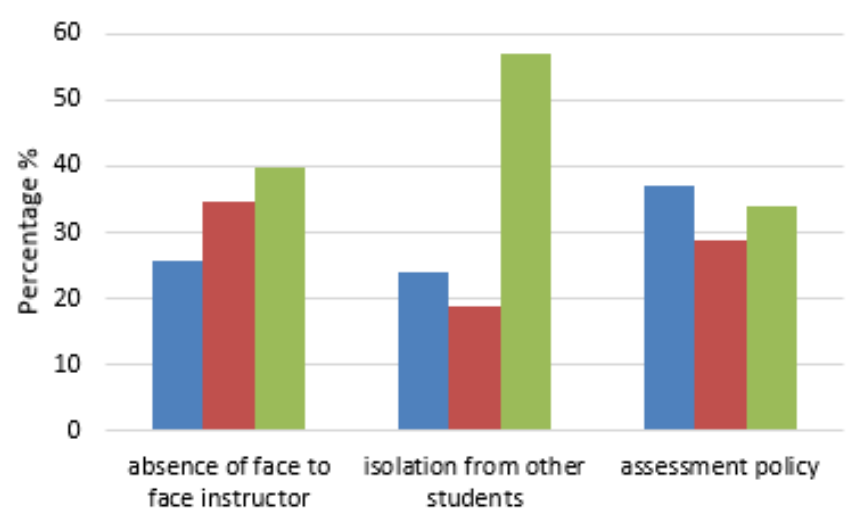

Fig. 4. Students' Feelings and Doubts.

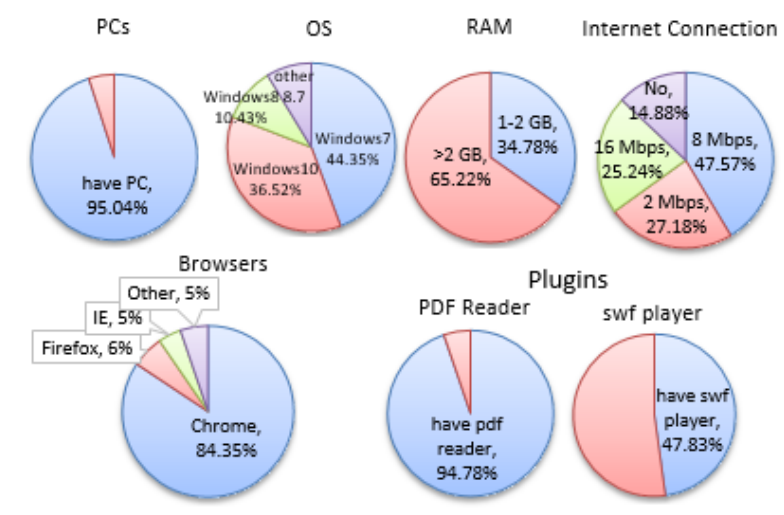

Fig. 5. Technical Infrastructure. 
Lastly, regarding disabilities, $25.62 \%$ students have poor vision. None of them are either visually impaired, color blind, deaf or have movement disabilities. People with disabilities may not properly access the course (risk factor).

\section{B. Satisfaction Surveys}

Satisfaction surveys involve quantitative and qualitative assessments. Quantitative assessment targets the learners in purpose of measuring how satisfied they were with the course. Each quantitative assessment item is associated with a risk factor. Based on students' reaction towards each item, we can measure how the model and the proposed risk management strategies were effective in mitigating each risk factor. Qualitative assessment targets other stakeholders (i.e. mainly development team) to measure how specific-related risk factors are mitigated. Below, satisfaction surveys results are introduced based on risk factors categories. The last part of the survey (i.e. Global items) involves general question items to measure how students are satisfied with the course in general.

- Content Risks

1) Quantitative analysis: Concerning content risks (see Table XII), students reacted positively towards most items with a mean average value equals 4.0. Items 1-5, 7-11, and 13 have mean values greater than or equal 4 , then, according to [51] these responses are described as "strong". Items 6, 12, and 14 have mean values between 3.5 and 4 then they are considered "solid". In order to assess the variety in responses, standard deviation was calculated for each item. As appears in Table XII, all standard deviation values are around 1 which indicates little variations in responses. Moreover, the most frequent answer for all items were either Strongly Agree or Agree (mode $=5$ or 4 ). This implies that content risk factors were mitigated very well. The solid mean values for items 6 , 12 , and 14 indicates that risk factors 6,15 , and 17 were mitigated but special attention should be paid in the future to increase students' satisfaction towards items 6,12 , and 14. In other words, new mitigation strategies should be followed to increase course interactivity and simplify the content and language. From another point of view, low values in language simplicity could be due to students' low fluency in English language in general (only $45.45 \%$ of the students said they are fluent). Moreover, the loading delay encountered could be ascribed to the relatively low Internet connection speed (74.75\% of department's students have download speeds up to only 8 Mbps).

2) Qualitative analysis: Regarding risks 7, 8, 9, 18, and 19, development team were enquired to assess how these risks were mitigated. They said that they faced no difficulties in working with different types of media content due to the availability of tools, professionals and the training sessions they had. When questioned about the requirements change, they reported that they had few challenges since the content was implemented incrementally in iterations with a continuous review with the SME; changes were adopted early. Content developers reported that they had very few difficulties in collecting material; they employed social networks, and used high quality books and web links to write high quality content. When asked about their familiarity with the domain, content developers said that they are unfamiliar with RE domain but they could overcome this risk by preparing the script jointly with the content providers and SMEs. Developers also reported that they had no problems in deploying the e-Content into the LMS since they had published into as shareable format (i.e. SCORM). Hence, also risk factors 7, 8, 9, 18, and 19 were mitigated successfully.

- Process Risks

1) Quantitative analysis: Regarding process risks (see Table XIII), with mean values greater than 4, students exhibited strong satisfaction towards items 15-26 (except 22) regarding feel of isolation (item 22), a solid mean value of 3.8 was obtained. Indeed, $70.37 \%$ did not feel isolated from other colleges which is slightly larger than the $(57.02 \%)$ who were worried about this issue before taking the course. More mitigation strategies should be taken to increase this percentage. The items mark little variances since almost all items values are around 1. Also, the mode was either 4 or 5 . This implies that risk factors 20-26, 28-29, and 31-32 were mitigated very well.

2) Qualitative analysis: Concerning risks 27 and 30, development team were enquired to assess how these risks were mitigated. They said that they faced very little communication problems because they all work in the same institution (i.e. HU). Regarding access authorization, they said that they did the testing using student accounts to make sure that they are given the right permissions. Hence, also risk factors 27 and 30 were mitigated successfully.

TABLE XII. Students' SATISFAction Survey Results - CONTENT Risks ITEMS

\begin{tabular}{|c|c|c|c|c|c|}
\hline$\stackrel{\overrightarrow{9}}{\Xi}$ & Description & $\stackrel{3}{3}$ & $\mathscr{\theta}$ & 文 & 릉 \\
\hline 1 & I was able to navigate the course easily & 4.1 & 1.1 & 5 & 1 \\
\hline 2 & The course was easy to use & 4.1 & 1.1 & 5 & 2 \\
\hline 3 & $\begin{array}{c}\text { I could easily access course content and } \\
\text { activities }\end{array}$ & 4.3 & 1.1 & 5 & 3 \\
\hline 4 & The course was interesting & 4.1 & 1.2 & 5 & 4 \\
\hline 5 & I liked the design of the course & 4.0 & 1.1 & 5 & 5 \\
\hline 6 & The course was highly interactive & 3.8 & 1.0 & 4 & 6 \\
\hline 7 & $\begin{array}{c}\text { Media (images, sounds, animations, videos) } \\
\text { quality was high }\end{array}$ & 4.0 & 1.1 & 5 & 10 \\
\hline 8 & $\begin{array}{c}\text { There was no large delay in loading media } \\
\text { elements }\end{array}$ & 4.0 & 1.1 & 5 & 11 \\
\hline 9 & $\begin{array}{c}\text { Course design and components were } \\
\text { consistent }\end{array}$ & 4.0 & 1.0 & 4 & 12 \\
\hline 10 & $\begin{array}{c}\text { The course was free of syntactical, } \\
\text { grammatical errors and mistaken } \\
\text { information }\end{array}$ & 4.0 & 1.1 & 5 & 13 \\
\hline 11 & $\begin{array}{l}\text { The organization of the course into units and } \\
\text { subunits was clear }\end{array}$ & 4.2 & 1.0 & 5 & 14 \\
\hline 12 & The content was easy to understand & 3.9 & 1.0 & 4 & 15 \\
\hline 13 & $\begin{array}{l}\text { The objectives and outlines for each module } \\
\text { were clear }\end{array}$ & 4.2 & 1.0 & 5 & 16 \\
\hline 14 & The language was simple and clear & 3.8 & 1.2 & 5 & 17 \\
\hline
\end{tabular}


TABLE XIII. STUdENTS' SATISFACTION SURVEY Results - Process RISKS ITEMS

\begin{tabular}{|c|c|c|c|c|c|}
\hline$\overline{\widetilde{\Phi}}$ & Description & $\stackrel{3}{a}$ & $\Omega$ & 光 & 尔 \\
\hline 15 & $\begin{array}{l}\text { Timing and sequencing of topics and other } \\
\text { activities were clear }\end{array}$ & 4.1 & 1.1 & 5 & 20 \\
\hline 16 & $\begin{array}{l}\text { The aims and objectives of the course were } \\
\text { achieved }\end{array}$ & 4.1 & 1.1 & 5 & 21 \\
\hline 17 & $\begin{array}{l}\text { Assignments and exams were related to the } \\
\text { materials taught in the class }\end{array}$ & 4.3 & 1.0 & 5 & 22 \\
\hline 18 & Assessments were satisfactory & 4.2 & 1.0 & 5 & 22 \\
\hline 19 & $\begin{array}{l}\text { Grading criteria were outlined in the } \\
\text { syllabus }\end{array}$ & 4.4 & 1.0 & 5 & 23 \\
\hline 20 & $\begin{array}{l}\text { Assessment procedure can NOT be easily } \\
\text { violated (i.e. cheating, unauthorized access, } \\
\text { impersonate, etc.) }\end{array}$ & 4.0 & 1.1 & 5 & 24 \\
\hline 21 & $\begin{array}{l}\text { I would prefer to take this course online } \\
\text { rather than in a traditional classroom }\end{array}$ & 4.0 & 1.3 & 5 & 25 \\
\hline 22 & I did not feel isolated from my colleagues & 3.8 & 1.2 & 4 & 26 \\
\hline 23 & $\begin{array}{l}\text { The unit's modules were delivered onto } \\
\text { Moodle on time }\end{array}$ & 4.3 & 1.0 & 5 & 28 \\
\hline 24 & $\begin{array}{l}\text { The technical support for this course was } \\
\text { effective }\end{array}$ & 4.1 & 1.0 & 5 & 29 \\
\hline 25 & $\begin{array}{l}\text { References and copyrights were declared } \\
\text { clearly }\end{array}$ & 4.1 & 1.1 & 5 & 31 \\
\hline 26 & I was able to know what and how to learn & 4.2 & 1.0 & 5 & 32 \\
\hline
\end{tabular}

- Technology Risks

1) Quantitative analysis: Regarding technology risks (see Table XIV), students reacted positively towards items 27-28 with mean values of 3.7 and 3.9 respectively (solid values) and an average value of 3.8. Also, the mode for both was 5 . This implies that risk factors 34,36 were mitigated very well. Regarding Browser incompatibility risk (factor 35), students were asked to mention the browsers they used to navigate the course. A percentage of $72.66 \%$ of students used Internet Explorer, 91.37\% used Google chrome, $15.83 \%$ used safari, $10.07 \%$ used Firefox, and $24.46 \%$ used android Internet browser. Hence, the course could be viewed using different browsers; avoiding risk 35.

2) Qualitative analysis: Concerning update and upgrade risks (Factor 38), development team reported that they did not face any update problem since they did not perform any update or upgrade during the delivery phase of the course in order to avoid these issues. The vast majority of the students (as from the pre-survey) reported that they have personal computers which would eliminate Factor 37. Moreover, a computer lab was dedicated to facilitate students' access to course content.

TABLE XIV. Students' Satisfaction Survey Results - Technology RISKS ITEMS

\begin{tabular}{|c|c|c|c|c|c|}
\hline $\overrightarrow{\mathbb{\Phi}}$ & Description & $\stackrel{3}{3}$ & 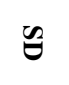 & $\frac{2}{2}$ & 尔 \\
\hline 27 & $\begin{array}{l}\text { I could access the course even if the main } \\
\text { server is down }\end{array}$ & 3.7 & 1.13 & 5 & 34 \\
\hline 28 & $\begin{array}{l}\text { No significant drop in performance occurs } \\
\text { when large number of students access the } \\
\text { server concurrently (i.e. exams) }\end{array}$ & 3.9 & 1.12 & 5 & 36 \\
\hline
\end{tabular}

\section{- Human Risks}

1) Quantitative analysis: Obviously human risks were mitigated well (see Table XV). Students reacted positively towards items 29-33 mean values above 4. Moreover, the most frequent answer (mode) for all items was Strongly Agree. This implies that the risk factors 39-43 were mitigated very well.

- Global Items

The last part of the survey (see Table XVI) reflects global measures that assess the overall satisfaction of the RE course project. Concerning global items 34-38, a percentage of $83.33 \%$ of students said that the course saved their time with a mean of 4.3 . On the other hand, $68.52 \%$ said that the course saved their money with a mean of 3.9. $77.16 \%$ recommend other students to take this course online in contrast with only $47.93 \%$ who had preferred, in the students pre-analysis, to take this course totally online. Moreover, $73.46 \%$ would like to take other online courses in the future. Finally, overall, $83.95 \%$ were satisfied with the course in general with a mean of 4.2. This implies that students generally were highly satisfied with the course.

TABLE XV. STUdENTS' SATISFACTION SURVEy RESUlTS - HumAn RiskS ITEMS

\begin{tabular}{|c|c|c|c|c|c|}
\hline$\stackrel{\vec{\Phi}}{\mathbf{g}}$ & Description & $\begin{array}{l}3 \\
\stackrel{3}{9}\end{array}$ & g & है & 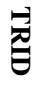 \\
\hline 29 & $\begin{array}{l}\text { The tutor was experienced in e-Learning } \\
\text { issues }\end{array}$ & 4.1 & 1.01 & 5 & 39 \\
\hline 30 & $\begin{array}{l}\text { The tutor was motivator and e-Learning } \\
\text { supportive }\end{array}$ & 4.2 & 0.97 & 5 & 40 \\
\hline 31 & I was motivated to take this course online & 4.1 & 1.16 & 5 & 41 \\
\hline 32 & $\begin{array}{l}\text { I already have the required computer } \\
\text { skills }\end{array}$ & 4.3 & 1.05 & 5 & 42 \\
\hline 33 & $\begin{array}{l}\text { The tutor was accessible and prepared to } \\
\text { teach the course online }\end{array}$ & 4.2 & 1.04 & 5 & 43 \\
\hline
\end{tabular}

TABLE XVI. StUdENTS SATISFACTION SURVEY - GLOBAL ITEMS

\begin{tabular}{|c|c|c|c|c|c|}
\hline $\overrightarrow{\widetilde{\Phi}}$ & Description & $\begin{array}{l}\text { 尚 } \\
\stackrel{\Xi}{=}\end{array}$ & $\mathscr{\theta}$ & के & 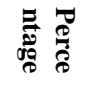 \\
\hline 34 & $\begin{array}{l}\text { Taking the course online saved my } \\
\text { time }\end{array}$ & 4.3 & 1.1 & 5 & $83.33 \%$ \\
\hline 35 & $\begin{array}{l}\text { Taking the course online saved my } \\
\text { money }\end{array}$ & 3.9 & 1.2 & 5 & $68.52 \%$ \\
\hline 36 & $\begin{array}{l}\text { I recommend other students to take } \\
\text { this course online }\end{array}$ & 4.1 & 1.2 & 5 & $77.16 \%$ \\
\hline 37 & $\begin{array}{l}\text { I would like to take other courses } \\
\text { online in the future }\end{array}$ & 4.0 & 1.3 & 5 & $73.46 \%$ \\
\hline 38 & $\begin{array}{l}\text { Overall, I would rate this course } \\
\text { Excellent }\end{array}$ & 4.2 & 1.0 & 5 & $83.95 \%$ \\
\hline
\end{tabular}

\section{Grades Analysis}

In order to validate the effectiveness of the proposed model, the quality of the e-Content and the e-Learning process was evaluated. Students' grades were used as a measurement for the quality of the e-Course content and process. In this section, students' results along six semesters (during 20152017) of the electronic delivery of the course are introduced in Table XVII. In contrast, students' results along the preceding three semesters (during 2014-2015) of the traditional delivery 
of the course are also introduced Table XVIII. Then, a comparison between the results of the electronic delivery versus the traditional delivery is introduced in Fig. 6.

Table XVII shows that the students achieved good results in the electronic delivery form of the course. In compare with the traditional delivery of the course, Fig. 6 shows that eCourse students performed similarly or even better in most categories. The percentage of students who failed in RE eCourse along the semesters was $3.76 \%$ in contrast with $9 \%$ in the traditional course. Moreover, the percentage of students who got high grades (i.e. above B) in the e-Learning course is slightly larger than the traditional. For instance, a percentage of $9.13 \%$ of students got B in the e-Course whilst only $4 \%$ got B in the traditional. Another percent value of $8.06 \%$ of students got $\mathrm{B}+$ compared to $8 \%$ in the traditional. A percentage of $11.29 \%$ of online students got A- in contrast with $10 \%$ of the traditional, and $5.91 \%$ got $\mathrm{A}$ in the online, while $5 \%$ got the same mark in the traditional. These values indicate a high quality electronic course and therefore validate the effectiveness of the proposed proactive risk management model leveraged in the e-Course development and delivery.

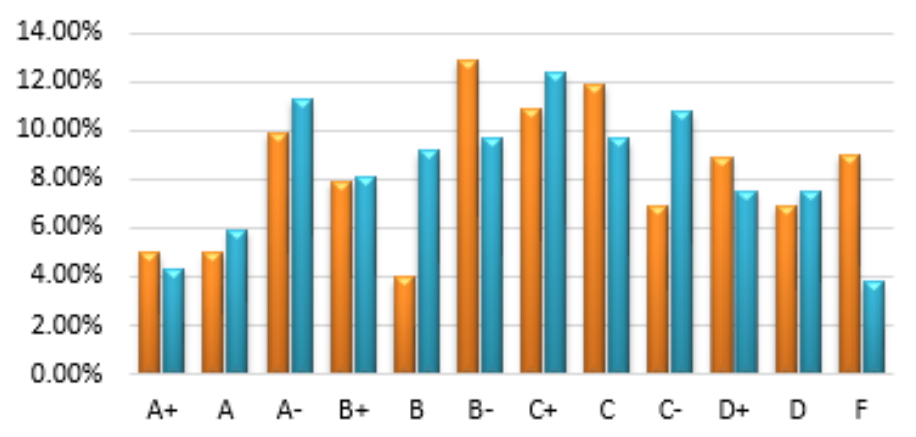

- Traditional Learning Percentage $\quad$ elearning Percentage

Fig. 6. e-Course Students Results Versus Traditional Results.

TABLE XVII. .RE E-COURSE STUDENTS GRADES

\begin{tabular}{|c|c|c|c|c|c|c|c|c|}
\hline 商 & Range & 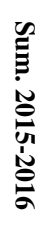 & 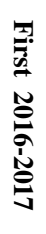 & 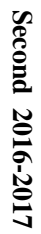 & 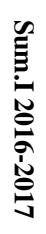 & 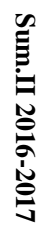 & 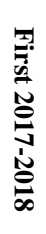 & 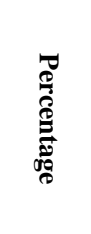 \\
\hline $\mathrm{A}+$ & $90.00-100.00$ & 2 & 2 & 2 & 1 & 0 & 1 & $4.30 \%$ \\
\hline $\mathrm{A}$ & $86.00-89.99$ & 2 & 3 & 2 & 2 & 2 & 0 & $5.91 \%$ \\
\hline A- & $82.00-85.99$ & 2 & 3 & 5 & 2 & 6 & 3 & $11.29 \%$ \\
\hline $\mathrm{B}+$ & $78.00-81.99$ & 5 & 2 & 4 & 0 & 2 & 2 & $8.06 \%$ \\
\hline $\mathrm{B}$ & $74.00-77.99$ & 2 & 6 & 1 & 4 & 1 & 3 & $9.14 \%$ \\
\hline B- & $70.00-73.99$ & 1 & 3 & 6 & 2 & 1 & 5 & $9.68 \%$ \\
\hline $\mathrm{C}+$ & $66.00-69.99$ & 3 & 4 & 3 & 5 & 4 & 4 & $12.37 \%$ \\
\hline $\mathrm{C}$ & $62.00-65.99$ & 2 & 4 & 1 & 7 & 1 & 3 & $9.68 \%$ \\
\hline C- & $58.00-61.99$ & 2 & 2 & 3 & 5 & 3 & 5 & $10.75 \%$ \\
\hline D+ & $54.00-57.99$ & 1 & 1 & 1 & 6 & 4 & 1 & $7.53 \%$ \\
\hline $\mathrm{D}$ & $50.00-53.99$ & 1 & 0 & 2 & 4 & 1 & 6 & $7.53 \%$ \\
\hline $\mathrm{F}$ & $0.00-49.99$ & 1 & 0 & 1 & 2 & 3 & 0 & $3.76 \%$ \\
\hline & Total & 24 & 30 & 31 & 40 & 28 & 33 & \\
\hline
\end{tabular}

TABLE XVIII. RE TRADITIONAL COURSE STUDENTS' GRADES

\begin{tabular}{|c|c|c|c|c|c|}
\hline \multirow{2}{*}{ Range } & $\begin{array}{c}\text { First } \\
\mathbf{2 0 1 4 -} \\
\mathbf{2 0 1 5}\end{array}$ & $\begin{array}{c}\text { Second } \\
\mathbf{2 0 1 4 -} \\
\mathbf{2 0 1 5}\end{array}$ & $\begin{array}{c}\text { First } \\
\mathbf{2 0 1 5 -} \\
\mathbf{2 0 1 6}\end{array}$ & Percentage \\
\hline A+ & $90.00-100.00$ & 2 & 2 & 1 & $5.00 \%$ \\
\hline A & $86.00-89.99$ & 2 & 2 & 1 & $5.00 \%$ \\
\hline A- & $82.00-85.99$ & 5 & 1 & 4 & $10.00 \%$ \\
\hline B+ & $78.00-81.99$ & 3 & 2 & 3 & $8.00 \%$ \\
\hline B & $74.00-77.99$ & 0 & 1 & 3 & $4.00 \%$ \\
\hline B- & $70.00-73.99$ & 2 & 3 & 8 & $13.00 \%$ \\
\hline C+ & $66.00-69.99$ & 2 & 5 & 4 & $11.00 \%$ \\
\hline C & $62.00-65.99$ & 2 & 3 & 7 & $12.00 \%$ \\
\hline C- & $58.00-61.99$ & 1 & 3 & 3 & $7.00 \%$ \\
\hline D+ & $54.00-57.99$ & 1 & 3 & 5 & $9.00 \%$ \\
\hline D & $50.00-53.99$ & 0 & 3 & 4 & $7.00 \%$ \\
\hline F & $0.00-49.99$ & 0 & 6 & 3 & $9.00 \%$ \\
\hline \multicolumn{2}{|c|}{ Total } & 20 & 34 & 46 & \\
\hline
\end{tabular}

Delivering the RE e-Course online for 6 semester achieved promising results. The authors believe that continuing delivering the course for many other semesters with a larger sample size and constant continuous improvement through the semesters will yield better results. The study revealed that technical issues related to hardware infrastructure, network connection, and server availability still would negatively affect communication and interactivity despite the good levels achieved. Moreover, the questionnaire was not checked for validity, this issue was beyond the current study.

\section{CONLUSION AND FUTURE WORK}

Improving education has been a prime priority for HEIs that seek to employ technology in learning to generate knowledgeable students. The success of e-Learning depends mainly on the quality of the course. Hence, in this paper, a proactive risk management framework that aims at ensuring high-quality e-Learning has been introduced. The framework was implemented in an online RE e-Course. In order to validate the effectiveness of the framework in developing the course, both users' satisfaction studies and students' grades analysis were conducted. This framework embeds an iterative approach to the development of instructional design products. Also, the framework is adaptable; it can be tailored to suit any e-Learning project according to its objectives, characteristics, audience and probable risks. Hence, the model proposed in this paper will serve as a tool for HEIs to define their customized models based on courses contexts and risks. The development of the RE e-Course was guided by the proposed framework. Its learning objectives and activities were designed and implemented according to good design principles and best practices in the literature with an eye towards avoiding eLearning risk factors. Throughout the RE course case study, this paper pointed out 43 e-Learning risk factors that need to be addressed and 148 risk management strategies needed to address these factors. Hence, the paper also sets the foundations to overcome these factors and to improve the eLearning approach in HE.

Satisfaction surveys analysis used Qualitative data and quantitative measurements; including mean, mode and standard deviation. These surveys were used to assess how each of these risks was mitigated. These surveys revealed that each of these 
risks has been mitigated to a certain degree. Moreover, students' grades analyses were conducted to assess the quality of the learning. The study revealed that participants who concluded the course were highly satisfied and achieved good results compared with traditional course. This implies the effectiveness of the proposed framework in developing and delivering high-quality e-Learning courses. The approach in this framework is not the only way to develop an effective eLearning content. Rather, it is a reasonable approach to ensure e-Learning project success and high-quality e-Courses based on the results we obtained. One dimension of the future work is to implement other online courses with a larger audience based on the framework to ensure generalizability of the framework. An issue is concerned with the validity of satisfaction surveys is left for future studies. Regarding items with less satisfaction values, further improvements are required to properly address the related risks. Furthermore, the correlation between students' satisfaction and the knowledge gain could be examined in the future.

\section{ACKNOWLEDGMENT}

This work has been accomplished through activities of two TEMPUS projects, the first entitled: "Modernizing Undergraduate Renewable Energy Education: EU Experience for Jordan - MUREE", project number 530332, and the second entitled: "Enhancing Quality of Technology-Enhanced Learning at Jordanian Universities", EQTeL, project number 544491. The authors acknowledge with gratitude and appreciation the generosity of the European Commission for its efforts to modernize and reform higher education in Jordan. The authors would like also to thank the Deanship of Scientific Research and Center of Academic Development and International Outreach at the Hashemite University for their efforts in facilitating working in above mentioned projects.

\section{REFERENCES}

[1] Barik, N., \& Karforma, S. (2012, January). Risks and remedies in elearning system. International Journal of Network Security \& Its Applications, 4(1), 51-59. doi:10.5121/ijnsa.2012.4105

[2] Jovanovic de Bozinoff, M., \& Taskosic, M. (2014). E-learning risks management as competitive advantage in institutions of higher education. Modern Computer Applications in Science and Education, (pp. 164-170). Cambridge.

[3] Mahmud, K., \& Gope, K. (2009). Challenges of implementing elearning for higher education in least developed countries: a case study on Bangladesh. Proceedings of the 2009 International Conference on Information and Multimedia Technology (pp. 155-159). Jeju Island, Korea: IEEE Computer Society, Washington, DC, USA. doi:DOI 10.1109/ICIMT.2009.27

[4] Dziuban, C., Graham, C. R., Moskal, P. D., Norberg, A., \& Sicilia, N. (2018). Blended learning: the new normal and emerging technologies. International Journal of Educational Technology in Higher Education, 15(3), 1-16.

[5] Mazohl, P., \& Makl, H. (2017). Quality assurance in blended learning a quality framework. In P. G. Mazohl, H. M. Mas, F. Breitenecker, A. Koerner, \& S. Winkler, Blended learning Quality - Concepts Optimized for Adult Education (pp. 23-37).

[6] Misut, M., \& Pribilova, K. (2015). Measuring of quality in the context of e-learning. social and behavioral sciences 177, (pp. 312 -319).

[7] Hoppe, G., \& Breitner, M. H. (2004). Business models for e-learning. Multikonferenz Wirtschaftsinformatik, (pp. 3-18).

[8] Woodill, G., \& Pasian, B. L. (2015). E-Learning project management: a review of the literature. In B. Pasian, \& G. Woodill, Plan to Learn: Case Studies in e-Learning Project Management (pp. 4-10).
[9] Durdu, P. O., Yalabik, N., \& Cagiltay, K. (2009). A distributed online curriculum and courseware development model. Educational Technology \& Society, 12(1), 230-248.

[10] Baruque, L. B., \& Brazil, A. L. (2014). Managing e-learning content development risks. Proceedings of E-Learn: World Conference on ELearning in Corporate, Government, Healthcare, and Higher Education. 1, pp. 145-152. New Orleans, LA, United States: Association for the Advancement of Computing in Education. doi:DOI: 10.13140/RG.2.1.3368.4003

[11] Vesper, J. L., Kartog ${ }^{` l u, ~ U ̈ ., ~ H e r r i n g t o n, ~ J ., ~ \& ~ R e e v e s, ~ T . ~ C . ~(2016) . ~}$ Incorporating risk assessment into the formative evaluation of an authentic e-learning program. British Journal of Educational Technology, 47(6), 1113-1124.

[12] Ifinedo, P. (2005). Uncertainties and risks in the implementation of an elearning information systems project in a higher-learning environment: viewpoints from Estonia. Journal of Information \& Knowledge Management, 4(1), 1-10.

[13] Bandaya, M. T., Ahmed, M., \& Jan, T. R. (2014). Applications of elearning in engineering education: a case study. Socil and Behavioral Sciences 123, (pp. $406-413$ ).

[14] Alqrainy, S., \& Hijazi, H. (2014). Managing risks in the system analysis and requirements definition phase. International Journal of Computer Applications, 23-29.

[15] Galvão, T. A., Neto , F. M., Campos, M. T., \& Júnior, E. d. (2012). An approach to assess knowledge and skills in risk management through project-based learning. International Journal of Distance Education Technologies, 10(3), 17-34.

[16] Khdour, T., \& Hijazi, H. (2012). A step towards preventive risk management in software projects. Proceedings of the International Conference on Software Technology and Engineering (ICSTE) (pp. 471478). Phuket, Thiland: ASME. doi:10.1115/1.860151_ch75

[17] Hijazi, H., Khdour, T., \& Alarabeyyat, A. (2012). A review of risk management in different software development methodologies. International Journal of Computer Applications, 45(7), 8-12. doi:10.5120/6790-9113

[18] Bratt, S. (2013). Agile instructional development framework: strategies for increasing learner and instructional designer collaboration. World Conference on Educational Multimedia, Hypermedia and Telecommunications. Victoria, British Columbia.

[19] Willeke, M. H. (2011). Agile in academics: applying agile to instructional design. 2011 Agile Conference, IEEE, (pp. 246-251).

[20] Cvetanovic, S. (2014). Development and enhancement of learning objects for e-learning systems using light agile method. The Fifth International Conference on e-Learning. Belgrade, Serbia.

[21] Albeanu, G. (2009). Agile CMMI for e-learning software development. Proceedings of the 5th International Scientific Conference eLSE "eLearning and Software for Education", (pp. 135-142). Bucharest.

[22] Raja, W., \& Nirmala, K. (2016). Agile development methods for online training courses web application development. International Journal of Applied Engineering Research, 11(4), 2601-2606.

[23] Uhomoibhi, J. O. (2006). E-learning and engineering education for sustainable development. 9th International Conference on Engineering Education. San Juan, PR.

[24] Fayyoumi, E., Idwan, S., AL-Sarayreh, K., \& Obeidallah, R. (2015). Elearning: challenges and ambitions at Hashemite University. Int. J. Innovation and Learning, 17(4), 470-485.

[25] Bralić, A., \& Divjak, B. (2018). Integrating MOOCs in traditionally taught courses: achieving learning outcomes with blended learning. International Journal of Educational Technology in Higher Education, 15(2), 1-16.

[26] Casanova, D., \& Moreira, A. (2017). A model for discussing the quality of technology-enhanced learning in blended learning programmes. International Journal of Mobile and Blended Learning (IJMBL), 9(4), 120.

[27] Hollowell, G. P., Brooks, R. M., \& Anderson, Y. B. (2017). Course design, quality matters training, and student outcomes. American Journal of Distance Education. 
[28] Atoum, A., Al-Zoubi, A., Abu Jaber, M., Al-Dmour, M., \& Hammad, B. (2017). A new approach for delivering e-Learning courses in Jordanian universities. Advances in Social Sciences Research Journal, 4(8), 1-13.

[29] Gómez-Rey , P., Barbera, E., \& Fernández-Navarro, F. (2016). Measuring teachers and learners' perceptions of the quality of their online learning experience. Journal of Distance Education, 146-163.

[30] Ghislandi, P., Raffaghelli, J., \& Yang, N. (2013). Mediated Quality: An approach for the e-Learning quality in higher education. International Journal of Digital Literacy and Digital Competence, 4(1), 56-73.

[31] Bremer, C. (2012). Enhancing e-learning Quality through the Application of the AKUE Procedure Model. Journal of Computer Assisted Learning, 28(1), 15-26.

[32] Ossiannilsson, E., \& Landgren, L. (2012). Quality in e-learning - a conceptual framework based on experiences from three international benchmarking projects. Journal of Computer Assisted Learning, 28(1), $42-51$.

[33] Lin, T.-C., \& Chen, C.-J. (2012). Validating the satisfaction and continuance intention of e-learning systems: combining TAM and IS success models. 10(1).

[34] Sarsa , J., \& Soler, R. (2012). E-Learning quality: relations and perceptions. International Journal of Information and Communication Technology Education, 8(2), 46-60.

[35] Marshall, S. (2012). Improving the quality of e-learning: lessons from the eMM. Journal of Computer Assisted Learning, 28(1), 65-78.

[36] Vázquez-Cano, E., \& García, M. S. (2015). Analysis of risks in a learning management system: a case study in the Spanish National University of Distance Education (UNED). New Approaches In Educational Research, 4(1), 62-68.

[37] Surcel, T., \& Reeiu, A. (2009). The risk management on developing the e-learning strategy. Proceedings 5th International Scientific Conference: e-Learning and Software for Education.

[38] Allen, S., \& Hardin, P. C. (2008). Developing instructional technology products using effective project management practices. Journal of Computing in Higher Education, 19(2), 72-97.

[39] Andersson, A. (2008). Seven major challenges for e-learning in developing countries: case study eBIT, Sri Lanka. International Journal of Education and Development using Information and Communication Technology, 4(3), 45-62.

[40] Angelou, G. N., \& Economides, A. A. (2007). E-learning investment risk management. Information Resource Management Journal, 20(4), $80-104$.
[41] Rodríguez, J. C., Granados, J. J., \& Muñoz, F. M. (2013). Engineering education through e-Learning technology in Spain. International Journal of Artificial Intelligence and Interactive Multimedia, 2(1).

[42] Benchicou, S., Aichouni, M., \& Nehari, D. (2010). E-learning in engineering education: a theoretical and empirical study of the Algerian higher education institution. European Journal of Engineering Education, 35(3), 325-343.

[43] Chandra, A. P., \& Samuel, R. S. (2010). E learning in engineering education: design of a collaborative advanced remote access laboratory. International Journal of Distance Education Technologies (IJDET), 8(2), 14-27.

[44] Rooij, V., \& Williams, S. (2010). Project management in instructional design: ADDIE is not enough. British Journal of Educational Technology, 41(5), 852-864. doi:10.1111/j.1467-8535.2009.00982.x

[45] Martens, A., \& Harrer, A. (2008). Software engineering in e-learning systems. In L. A. Tomei, Encyclopedia of Information Technology Curriculum Integration (pp. 782-789).

[46] Chimalakonda, S., \& Nori, K. V. (2012). A software engineering perspective for accelerating educational technologies. IEEE 12th International Conference on Advanced Learning Technologies (ICALT).

[47] Arimoto, M. M., Barbosa, E. F., \& Barroca, L. (2015). An agile learning design method for open educational resources. Frontiers in Education Conference (FIE), IEEE. El Paso, TX, USA.

[48] Hijazi, H., Alqrainy, S., Muaidi, H., \& Khdour, T. (2014). A framework for integrating risk management into the software development process. Research Journal of Applied Sciences, Engineering and Technology, 8(8), 919-928. doi:13329-RJASET-DOI

[49] Moreira, I. C., Ventura, S. R., Ramos, I., \& Rodrigues, P. P. (2013). Learner's satisfaction within a breast imaging e-Learning course for radiographers. Proceedings of the IEEE 26th International Symposium; Computer-Based Medical Systems (pp. 215-220). Porto, Portugal.: IEEE.

[50] Tullis, T., \& Albert, W. (2013). Measuring the user experience, second edition: collecting, analyzing, and presenting usability metrics. San Francisco, CA, USA: Morgan Kaufmann Publishers Inc.

[51] Winer, L., Di Genova, L., Vungoc, P. - A., \& Talsma, S. (2012). Interpreting end - of - course evaluation results. Montreal: Teaching and Learning Services, McGill University. 